DOI: $10.20472 / \mathrm{IAC} .2017 .33 .073$

\author{
VÁCLAV VYBÍHAL \\ University of Ss Cyril and Methodius in Trnava, Faculty of Social Sciences, Department of Public Administration, \\ Slovak Republic
}

\title{
THE FISCAL EFFECTIVENESS OF THE PROVISION OF INVESTMENT INCENTIVES
}

\begin{abstract}
:
Foreign direct investments undoubtedly have a significant impact on the national economy. They contribute to economic growth, to reducing the unemployment rate and they also positively affect other macroeconomic indicators. Foreign companies bring with them not only foreign capital that they invest in the host country, but also new technology, modern and more effective production and management methods, classic standards of business conduct, new jobs as well as opportunities for domestic suppliers.
\end{abstract}

Host countries then attempt to attract foreign investors via active policies through investment incentives and various preferential conditions for investing. Investment incentives for foreign investors are thus among the important public spending programs. Basic investment incentives in countries with transitive economies within the European Union include income tax credits, respectively tax holidays, the transfer of land for a subsidized price, one-time financial support for the creation of new jobs and financial support for retraining employees. The provision of investment incentives means not only an increase on the expenditure side of the public budget or a decrease of the income side of the public budget (due to tax credits), but it usually leads - as our research demonstrated - to a start of the influx of revenue sources for public budgets, already in the short or medium term horizon.

The aim of the research was to develop a methodology for measuring the fiscal effectiveness of provided investment incentives in the process of their implementation, to determine what the effects are on the income side of the national budget, and for this purpose construct an indicator of fiscal effectiveness whose functional and explanatory power would need to be tested in practice among the recipients of investment incentives.

The fiscal effectiveness of investment incentives was constructed as the share of outputs (in the form of revenues from taxes, social and health insurance, fees, savings on the expenditure side of the budget) on a unit of inputs (income tax credit, financial support for a created job, subsidy to cover the costs of employee retraining, administrative costs of collecting taxes, subsidies on the technical equipment of an area on which production is to be located, subsidy on the price of land). With regard for business plans, fiscal effectiveness was assessed for a period of 5 years from the approval and receipt of the investment incentive in a set of industrial enterprises in the Czech Republic. The research also covered results that were attained in Slovakia.

\section{Keywords:}

Foreign direct investment, investment incentives, fiscal effectiveness, industrial enterprises 
JEL Classification: L38, G39, H20 


\section{Introduction}

As a form of support for foreign direct investment, investment incentives play an important role in deciding upon the allocation of investment and are undoubtedly a priority among the interests of not only countries with economies in transition, but are also interesting to developed countries of Europe. They are provided in different forms or in combination of these forms. The variant applied in the Czech Republic consists mainly of tax breaks in the form of a $100 \%$ discount off income tax, subsidy for each job created, partial payment of the costs of the company to retrain employees and subsidies to promote the development of industrial zones.

Newly designed public expenditure programs play an important role in terms of further economic and social development of the Czech Republic. They aim to bring about economic recovery, promote active employment policy, contribute significantly to the restructuring of the national economy and - ultimately - increase the competitiveness of the Czech Republic.

A program of investment incentives was introduced in the Czech Republic in 2000 as an important and crucial form of investment support fully compatible with legal regulations of the European Union. According to the rules of the European Community, investment incentives are included in the category of regional state aid and should be offered especially for areas with lower income level and high unemployment and should address the basic economic parameters in structurally affected areas.

The Investment Incentives Act adopted in the Czech Republic in 2000 has been fully accepted by the European Commission which has contributed to the establishment of a fully transparent and trustworthy environment for foreign investors. Direct foreign investments were directed mainly into the automotive industry and related engineering, electronics and manufacturing industries. Lately, we have seen a trend towards significant increase of investments into information technology, strategic services and also into building logistics centres. The disadvantage of the development is that the bulk of foreign direct investment went into industries that are very sensitive to recession; investments into the food industry which is quite recession-resistant have been missing in the mix of foreign investments. This was, of course, reflected first in the unprecedented growth in gross domestic product in the years 2000 to 2008 and then in the subsequent decline and stagnation of GDP in the years 2009 to 2013.

Investment incentives are provided and financed from public budgets in the Czech Republic, especially from the state budget. Therefore, it is necessary to monitor the extent to which the funds provided by the state are recoverable and what the fiscal efficiency of investment incentives is in terms of income and expenditure of public budgets. It is an investment by the state which should have its return on investment and should bring benefits to the revenue side of the public budgets, in the form of multiplier effects if possible. 
It turns out that foreign capital brings new advanced technology, proven management practices, traditional standards of business conduct with a positive impact on employment, results in gross domestic product (GDP) growth, improves trade balance and other macroeconomic indicators in the economy. The micro-economic and noneconomic impacts are also economically significant. The said benefits of capital brought into the country support overall economic recovery and undoubtedly contribute to increasing the competitiveness of the Czech economy.

The aim of this paper is to highlight the importance of investment incentives for economic growth, evaluate findings of research on the detection of fiscal effectiveness of investment incentives as acquired by our own investigation in an environment of significant scale spanning 30 industrial enterprises that have been recipients of investment incentives during a 5-year period on the basis of methodological approach drawn up by us and verified in practice.

\section{Material and Methodology}

During his research activities, the author has focused primarily on the fiscal effectiveness of investment incentives as this topic has not yet received the necessary attention in those scientific studies and government documents that are available. Studies that would address the impact of inflow of foreign investments on creation of sources of revenue for public budgets are still non-existent in both domestic and foreign literature. It should be noted in this context that the provision of investment incentives not only increases the expenditure side of public budgets - especially the state budget - or reduces the revenue side of the public budget (due to the tax credit), but usually leads to the start of inflow in sources of revenue to public budgets, already in the short or medium term.

Effectiveness can be expressed in economic theory as the ratio between inputs and outputs, whereas an activity can be considered effective if all the resources are fully used at the highest possible efficiency and the amount of input brings about maximum output (Synek, 1996). The issue of effectiveness in relation to taxation and fiscal policy has been dealt with by Pudil, Vybíhal, Vítek and Pavel (2004).

Therefore, effectiveness is determined by the ratio of inputs and outputs and describes the most efficient use of economic resources to meet the needs of people. Therefore, the economy produces products in an efficient manner when it cannot produce more of one product without producing less of another product. An effective economy is therefore at the edge of its production capacity. This edge is such an economic result when there can be neither a reorganization nor a transaction that would increase the utility or satisfaction of another entity (Vybihal, 2004).

Under certain limited conditions, perfect competition leads to allocation effectiveness (called Pareto efficiency). In general, efficiency is such a use of economic resources that provides the maximum level of satisfaction achievable given the inputs and state 
of the technology. Stiglitz (1997) went further when he stated that economists always highlight effectiveness when considering various alternative programs and ask the question "how much would you be willing to pay for removal of a given ineffective measure?" to assess the degree of inefficiency.

Different income tax rates, different net fiscal benefits or burdens affect the location of economic activity and create a tendency not to allocate resources where their use is more efficient. This exactly is an important incentive for investors (an investor invests where the use of their resources is more effective, i.e. where the taxes are lower). This leads to distortion of allocation effectiveness world-wide (Musgrave and Musgrave, 1994). The decision on the location of production is therefore not always done on the basis of comparative advantage - i.e. the relative costs of resources - but it is quite frequently affected by different tax burdens.

When evaluating the fiscal effectiveness of investment incentives, it is necessary to set this indicator during the assessment of inputs and outputs so that the outputs reflect revenues from collected taxes and fees, i.e. the revenue sources of public budgets, and the inputs shall reflect the individual segments stimulating investment process, i.e. funds provided from the expenditure side of public budgets which should also generate economic growth and boost employment especially in geographical areas with relatively higher unemployment rates or in areas affected by the restructuring of the national economy.

The input database for modelling and evaluating fiscal effectiveness of investment incentives was populated by data obtained directly in 2013 from the accounting records of business entities that had received investment incentives.

We focused on a total of 30 companies doing business in the automotive industry, engineering, electrical engineering and glass-producing industries, the common denominator of which were new production areas, a high degree of robotization and production innovation, high-tech facilities including systems for designing products and strong supplier position including goodwill and a position of an excellent business partner in the eyes of renowned car manufacturers.

With regard to the specific situation in the identification of the database of the companies in question, a model (indicator) of fiscal effectiveness $\left(\mathrm{E}_{\mathrm{f}}\right)$ of provision of investment incentives has been constructed and gradually adjusted based on the following equation:

$$
T_{i p}+T_{y w}+T_{e d}+T_{e t}+T_{v c}+I_{s}+\ln +S+T_{l e}
$$

$E_{f}=$

$$
\mathrm{W}+\mathrm{R}+\mathrm{D}+\mathrm{C}+\mathrm{G}
$$

where the inputs (placed in the denominator in the model) in terms of categories of fiscal effectiveness of investment incentives are the actual expenditures of public budgets (and loss of income, if relevant), namely (in CZK): 
- Financial support per job created (W),

- Grants to cover part of the costs of retraining employees (R),

- The amount of tax credit off income tax (D),

- Administrative costs of tax collection (C),

- Subsidies to promote industrial zones $(G)$.

The outputs for monitoring fiscal effectiveness include the actual revenues from taxes and other revenues (the revenue side of public budgets), in particular:

- Tax on personal income from employment ( $\left.T_{i p}\right)$,

- Income tax levied at a special tax rate from an individual tax base ( $\left.T_{y w}\right)$,

- Road tax (Ted),

- Real property tax $\left(T_{e t}\right)$,

- Fees $\left(T_{y c}\right)$,

- Social security insurance $\left(I_{s}\right)$,

- Public health insurance $\left(\mathrm{I}_{\mathrm{h}}\right)$,

- Savings on the expenditure side of the state budget (S);

- Other tax revenues $\left(\mathrm{T}_{\mathrm{le}}\right)$.

It may be noted that the output that supports fiscal effectiveness of investment incentives may also include other economic benefits derived from the various support programs (e.g. support to contractors or to industrial zones, etc.). These effects are very difficult to measure or quantify.

In terms of methodological and substantive approach, the original model of fiscal efficiency was modified in the numerator so that it remains abstracted from value added tax levies. This is because the business units included in this survey exported about $92 \%$ of production and the tax deduction means that the input tax exceeds the output tax. In such cases, enterprises do not pay tax, but rather they cash in excess payments as the difference between output tax and input tax.

With regard to the principle and mechanism of value added tax (the tax is levied in the entire chain at each stage of processing for almost all production from taxpayers (suppliers) who reduce their output tax payable to the state by the input tax (reduced by a coefficient, if applicable) due to payment for purchases needed for the production of products), the model cannot reflect extensive tax deduction by the companies in question as technically it is not possible to quantify the amount of tax paid by the taxpayers of value added tax because of the very wide group of suppliers. It can be assumed, however, that the sum of value added tax paid in the entire production and distribution chain of taxpayers exceeds the aggregate of extensive tax deductions. 
The amount of the tax credit off income tax (100\% for 5 years) is not included in the expenditure side of public budgets, but is de facto a "loss of income" that could deliver effects in the form of revenue into public budgets. The international definition of "tax expenditure" is used for this instrument.

The outcome of the process of monitoring fiscal effectiveness is the actual revenue from taxes, social security and health insurance premiums and other general government revenue as a crucial source of revenue to public budgets. Certain role is played also by savings on the expenditure side of the state budget, such as savings in dole payments in case of a change of status of an individual job seeker to an employee.

When measuring the fiscal effectiveness of investment incentives, a series of methodological and practical problems arise that we have dealt with in the course of our research. For example, when evaluating the dynamics of the indicator of fiscal effectiveness, we did not take into account just the levies of value added tax, but also issues of the development of the inflation rate, time value of money, the ROI period of inputs, the type of investment (green field project, expansion, brown field project) or business sectors (automotive, mechanical, electronic, electrical, glass-producing, medical, woodworking, food processing or other sectors of the economy).

An important methodological issue is to decide upon the time interval in which to monitor the fiscal effectiveness of investment incentives. Given the fact that income tax credits are provided for 5 years and companies prepare business plans for 5 -year periods, calculation of fiscal effectiveness is done in five-year intervals starting from the year following the date of granting the investment incentives. Therefore, for example, financial support to the creation of new jobs or benefits consisting of lower land prices have to be deferred for a period of 5 years. According to our experience and the results of expert analysis, five-year period is considered to be optimal in this regard.

We have already discussed methodological issues of measuring fiscal effectiveness of investment incentives in the previous research period (Vybíhal 2002, 2003 or Šachrová, Vybíhal 2002 and 2004).

\section{The Results of the Research}

In the course of evaluating fiscal effectiveness of investment incentives in terms of time, the basic unit was the five-year period beginning in the year following the date of granting of the investment incentives, i.e. the evaluation was conducted for the years 2009 to 2013.

Upon verification of the model of fiscal effectiveness in the list of businesses, we found the value of the indicator of fiscal effectiveness $E_{f}>1$ in all cases. This means that we can consider the use of state funds in the group of surveyed companies to be effective. This is illustrated by the information listed in Tab. 1 which also shows the 
contribution to public budgets measured by the amount of outputs exceeding the inputs in total in the model of fiscal effectiveness during the five years. For example, for enterprise "1", this effect is CZK 88 million for the said period, i.e. CZK 17.6 million per year (exchange rate $1 \mathrm{EUR}=27.450 \mathrm{CZK}, 1 \mathrm{USD}=20.250 \mathrm{CZK}$ as of July 31 , 2014).

Table 1 Summary of the Fiscal Effectiveness Performance Levels of Investment Incentives $\left(E_{f}\right)$ Achieved for the Period 2009-2013 in the Research Group of Enterprises Operating in the Market in the Czech Republic

\begin{tabular}{|l|l|l|}
\hline Entreprise & $\begin{array}{l}\text { Value } \\
\text { Indicator } \\
\text { Ef }_{\text {of }}\end{array}$ & $\begin{array}{l}\text { Calculation of the } \\
\text { Effect } \\
\text { (million CZK) }\end{array}$ \\
\hline $\mathbf{1}$ & 1.30 & 88 \\
\hline $\mathbf{2}$ & 2.99 & 121 \\
\hline $\mathbf{3}$ & 3.31 & 127 \\
\hline $\mathbf{4}$ & 1.08 & 48 \\
\hline $\mathbf{5}$ & 3.76 & 146 \\
\hline $\mathbf{6}$ & 1.47 & 107 \\
\hline $\mathbf{7}$ & 6.34 & 622 \\
\hline $\mathbf{8}$ & 1.17 & 21 \\
\hline $\mathbf{9}$ & 9.18 & 309 \\
\hline $\mathbf{1 0}$ & 15.23 & 422 \\
\hline $\mathbf{1 1}$ & 2.69 & 117 \\
\hline $\mathbf{1 2}$ & 1.30 & 132 \\
\hline $\mathbf{1 3}$ & 2.99 & 122 \\
\hline $\mathbf{1 4}$ & 3.31 & 127 \\
\hline $\mathbf{1 5}$ & 1.08 & 48 \\
\hline $\mathbf{1 6}$ & 3.76 & 146 \\
\hline $\mathbf{1 7}$ & 1.28 & 323 \\
\hline $\mathbf{1 8}$ & 2.06 & 158 \\
\hline $\mathbf{1 9}$ & 4.23 & 91 \\
\hline $\mathbf{2 0}$ & 2.78 & 58 \\
\hline $\mathbf{2 1}$ & 7.98 & 537 \\
\hline $\mathbf{2 2}$ & 1.42 & 151 \\
\hline $\mathbf{2 3}$ & 4.82 & 290 \\
\hline $\mathbf{2 4}$ & 1.68 & 101 \\
\hline $\mathbf{2 5}$ & 2.35 & 129 \\
\hline $\mathbf{2 6}$ & 3.58 & 178 \\
\hline $\mathbf{2 7}$ & 2.47 & 200 \\
\hline $\mathbf{2 8}$ & 6.38 & 374 \\
\hline $\mathbf{2 9}$ & 3.86 & 130 \\
\hline $\mathbf{3 0}$ & 2.84 & 331 \\
\hline Total & $\mathbf{3 . 6 2}$ & $\mathbf{5 7 5 4}$ \\
\hline & & \\
\hline
\end{tabular}

Source : author's calculations based on databases provided by the companies. 
Table 2 shows the structure of inputs and outputs of the model of fiscal effectiveness measured during 5 years for the group under consideration as a whole. The overall effect for the period amounted to CZK 5,754,000.

It turns out that in the area of inputs, the recipients of investment incentives see the reduction of income tax of legal persons as a decisive factor and the biggest advantage on the output (the revenue side of public budgets) is the revenue from social security contributions and personal income taxes from depended activities (taxation of employment). The said revenues of public budgets (the outputs) are tied to the territory of the Czech Republic, are transparent, easily determinable, objectively defined and cannot be transferred outside the Czech Republic, as opposed to profit or the income tax base (in the case of failure to receive tax credits on income or "tax holidays"). This can be seen as the decisive fiscal benefit of the entire system of investment incentives.

\section{Table 2 Structure of Inputs and Outputs of the Model of Fiscal Effectiveness}

\begin{tabular}{|l|l|}
\hline Category & $\begin{array}{l}\text { Share } \\
\text { in \% }\end{array}$ \\
\hline The amount of tax credit on income & 98.3 \\
Financial support (subsidy) per job created & 1.0 \\
Subsidy to cover part of the cost of & 0.6 \\
retraining & \\
Other inputs (land price subsidies) & 0.1 \\
Total inputs & $\mathbf{1 0 0 . 0}$ \\
\hline Tax on personal income from employment & 22.8 \\
Social security insurance & 56.2 \\
Public health insurance & 20.4 \\
Other outputs (other taxes and fees) & 0.6 \\
Total outputs & $\mathbf{1 0 0 . 0}$ \\
\hline
\end{tabular}

Source : author's calculations.

\section{Conclusions}

The paper presents the results of research conducted by our own investigation of recipients of investment incentives. The sample consisted of 30 companies from the automotive, engineering, electrical and glass-producing industries the common denominator of which were new production areas, a high degree of use of robotics and production innovation, high-tech facilities including systems for product design and strong supplier position including the status of an excellent business partner in the eyes of well-known car manufacturers. These are all businesses providing high added value (on average 1.1 million CZK per employee per year). The investments were mainly into green field projects.

In terms of achieved level of fiscal efficiency, it can be concluded that the state's investment into investment incentives has been efficient and recoverable from the fiscal (tax revenue) point of view. 
Although some differences are clear when it comes to the indicator of fiscal effectiveness of investment incentives, the common denominator of all the units in the examined group (in addition to the already mentioned high degree of added value) is export performance, product quality in accordance with the requirements of ISO 9001 and environmental certification under ISO 14001, and last but not least, aboveaverage wages that directly enhance the advance payments towards income tax from employment, payment of health insurance and social security premiums and contribute significantly to increasing the fiscal efficiency of investment incentives.

To maintain a relatively successful trend of development in foreign direct investment and related investment incentives, it will be necessary to further improve the investment and business environment in the future, to remove specific weaknesses resulting from the performed evaluation of the investment climate by investors doing business in the Czech Republic and to monitor the scope and improve the system of investment incentives and follow-up programs.

\section{Discussion}

It turns out that business support through offering investment incentives not only brings positive impact on the economy of the Czech Republic, but also means a higher level of competitiveness of the country. In addition to the fiscal effects, obvious improvements include positive impact on employment, although many employees of recipients of investment incentives are not employed from among job seekers registered at the employment office.

Foreign investors appreciate the Czech Republic not only as a country with a significant engineering tradition, but they also value the infrastructure of subcontractors and of the workforce, location in central Europe with fast supply links to automakers in Europe due to proximity to European customers, knowledge of languages by the management, high level of telecommunications and international connectivity. One of the few drawbacks to businesses operating in the automotive sector is a higher degree of sensitivity to the existence and progress of the economic recession.

Foreign direct investment plays an important role in the Slovak Republic where it is beneficial to the economic development potential of the country. The author's research examining the issue of the effectiveness of fiscal incentives will focus on that EU country in the next period of time.

It can be concluded that investment incentives are also a tool to overcome economic recession and increase export performance and are also an important tool in solving regional problems of unemployment and a vehicle of transfer of know-how and modern technology into the Czech Republic. Incentives for investors thus become one of the sources of economic recovery and a signal for other countries that the Czech Republic is on the upward trajectory in terms of inflow of foreign investment and that 
the country wants and needs foreign investors. Over $80 \%$ of the investment comes from EU countries, mainly from Germany, Austria, the Netherlands and France. A significant part in the investments also flow from investors from Japan, South Korea, Canada and USA. Czech investors use the system of investment incentives as well.

Currently, the state seeks to ensure that investment incentives be directed primarily towards sectors with higher added value, with a focus on activities that promote the export performance and do not increase imports at the same time. An unmistakable factor in the presence of large investors is the fact that foreign investment brings new jobs and generates spent by households which also contributes to the development of the tertiary sector, i.e. trade and services.

Other major influences include positive effects of foreign direct investments on productivity in the host country as the positive impact of foreign direct investments on the productivity of domestic firms is also evident as an indirect influence through technological spillovers (spillovers of technological knowledge) or through competitive pressure by foreign investors. The said effects also include the acquisition of new modern technologies, connection to trans national distribution networks, improving the quality of production in accordance with the requirements of international certifications, regeneration of the area, increasing the rate of improvement of infrastructure in the adjacent industrial areas, improving the trade balance of the country and also multiplier effects resulting from the effective provision of investment incentives.

It is clear that this process also entails disadvantages. These include excessive dependence on foreign countries and the global economic cycle, the focus on sectors with a higher degree of sensitivity to the existence and progress of the economic recession which could be potentially dangerous to employment and economic growth. As a negative consequence, high concentration of foreign manufacturers may occur in many areas.

Vybihal (2002) highlights another effect of investment incentives that reaches to areas of ecological, social, psychological, personal and other. In this context, it is necessary to consider the environmental aspects of implementation of industrial zones, particularly in terms of positive and especially negative externalities (annexation of quality agricultural soils, the quality of life of citizens in the vicinity of industrial zones, etc.).

\section{References}

SYNEK,M. et al. Manažerská ekonomika. [Managerial Economy] Praha : Grada Publishing, 1996. 456 p. ISBN 80-7169-211-5.

MUSGRAVE, R.A. - MUSGRAVE, P. B. Veřejné finance $v$ teorii a praxi. [ Public Finance in Theory and Practice]. Praha : Management Press, 1994. 946 p. ISBN 80-85603-76-4.

PUDIL, P. - VYBÍHAL,V. - VÍTEK, L. - PAVEL, J. Zdanění a efektivnost. [Taxation and Effectiveness]. Praha : Eurolex Bohemia, 2004. 158 p. ISBN 80-86861-07-04. 
STIGLITZ, J. E. Ekonomie veřejného sektoru. [Public Sector Economics]. Praha : Grada Publishing, 1997. 664 p. ISBN 80-7169-454-1.

ŠACHROVÁ,V.-VYBíHAL,V. Investiční stimuly jako determinanty konkurenceschopnosti. [Investment Incentives - determinants of competitiveness]. Sborník př́spěvků z odborného semináře konaného dne 11.9. a 12.9.2002. [Proceedings]. Praha : Česká zemědělská universita, Provozně ekonomická fakulta, Katedra obchodu a financí, 2002, pp. 115-120, ISBN 80-2130920-2.

VYBÍHAL,V. Kritéria efektivnosti veřejných výdajových programů.[Criterions of Effectiveness Public Expenditures Programmes] In : Sborník referátů z teoretického semináře „Teoretické a metodické otázky analýz veřejných výdajových programů. [Proceedings]. Brno : Masarykova univerzita, 2002. pp. 208-213. ISBN 90-2102816-5.

VYBÍHAL,V. K problematice efektivnosti poskytování investičních pobídek. [On problem of fiscal effectiveness of investment incentives]. Sborník příspěvků z VIII. mezinárodní odborné konference „Teoretické a praktické aspekty veřejných financí. [Proceedings of International Scientific Conference]. Praha : Vysoká škola ekonomická, 2002, pp. 115-122. ISBN 80-2450270-4.

VYBÍHAL,V. K problematice měření fiskální efektivnosti investičních pobídek. [On probleme of measurement of fiscal effectiveness of investment incentives]. In : Sborník prací z mezinárodní vědecké konference „Agrární perspektivy XII. Nová ekonomika a rozšiřrení EU“ 18.-19.9.2003. Díl I. [Proceedings of International Scientific Conference]. Praha : ČZU, 2003. pp. 381-385. ISBN 80213-1056-1.

VYBÍHAL, V. - ŠACHROVÁ, V. K možnostem hodnocení fiskální efektivnosti investičních stimulů. [On possibility of evaluate of fiscal effectiveness investment stimulus] In : Zborník vedeckých prác z konference "Medzinárodne vedecké dni 2004 - Európska integrácia - výzva pre Slovensko“, 20. - 21.5.2004. [Proceedings of International Scientific Conference]. SPU : Nitra, 2004. s. 149 160. ISBN 80-8069-355-2.

VYBíHAL,V. The Effectiveness of Investment Incentives Provision. In : Proceeding „Bangkok International Conference on Applied Business Research“, December 1-3, 2004. Bangkok, Thailand : Kasetsart University, 2004. s. 91-92. ISBN 974-537-621-3. 